\title{
Outbreaks of rhinofacial and rhinopharyngeal zygomycosis in sheep in Paraíba, northeastern Brazil ${ }^{1}$
}

\author{
Franklin Riet-Correa ${ }^{2}$, Antônio F.M. Dantas², Edísio O. Azevedo², Sara D.V. \\ Simões ${ }^{2}$, Silvana M.S. Silva ${ }^{3}$, Raquel Vilela ${ }^{4}$ and Leonel Mendoza ${ }^{4}$
}

\begin{abstract}
Riet-Correa F., Dantas A.F.M., Azevedo E.O., Simões S.D.V., Silva S.M.S., Vilela R. \& Mendoza L. 2008. Outbreaks of rhinofacial and rhinopharyngeal zygomycosis in sheep in Paraíba, northeastern Brazil. Pesquisa Veterinária Brasileira 28(1):29-35. Hospital Veterinário, CSTR, Universidades Federal de Campina Grande, Patos, PB 58700-000, Brazil. E-mail: franklin.riet@pq.cnpq.br

Two outbreaks of zigomycosis with rhinofacial and two other with rhinopharyngeal lesions involving fungi with filamentous coaenocytic hyphae characteristic of entomophthoramycetous fungi are reported in the state of Paraíba, northeastern Brazil. One outbreak of rhinofacial zygomycosis occurred during the rainy season affecting 5 sheep. Another outbreak of the clinical form affected one out of 40 sheep during the dry season. Common clinical signs of the rhinofacial infection were bilateral serosanguineous nasal discharge with swelling of nostrils, upper lip, and the skin of the face. At necropsy the nasal mucosa showed dark brownish ulcerated areas which extended from the mucocutaneous region to $10 \mathrm{~cm}$ inside the nasal vestibule. The mucosa of the hard palate was also ulcerated. The cutting surface of nostrils and palate showed a brownish or red spongeous tissue of friable consistency. One outbreak of rhinopharyngitis took place on an irrigated coconut farm; 7 out of 60 adult sheep were affected. Another outbreak affected a sheep in a flock of 80 during the dry season. Clinical signs as noisy respiration and dyspnoea due to mechanical blockage of the nasal cavities, swelling of the nostrils, and serosanguineous nasal discharge were observed. Six out of 8 sheep in this group showed exophthalmia, keratitis and unilateral corneal ulceration of the eye. The sheep either died of their infection or were euthanized after a clinical course of 7-30 days. At necropsy there was a dense yellow exudate in the nasopharyngeal area affecting the ethmoidal region, turbinate bones, paranasal sinuses, hard and soft palates, orbital cavity, pharynges, regional muscles and lymph nodes. Histopathologically both forms of the disease showed multifocal granulomas with an eosinophilic necrotic reaction (Splendore-Hoeppli phenomenon) containing ribbon type coenocytic hyphae with 7-30um in diameter similar to hyphae of zygomycetous fungi, possibly Conidiobolus spp. Outbreaks of both forms of mycotic rhinitis are common in northeastern Brazil and in other regions of the country.
\end{abstract}

INDEX TERMS: Conidiobolomycosis, zygomycosis, sheep, semiarid.

\footnotetext{
${ }^{1}$ Received on August 15, 2007.

Accepted for publication on October 2, 2007.

${ }^{2}$ Hospital Veterinário, Centro de Saúde e Tecnologia Rural (CSTR), Universidades Federal de Campina Grande, Patos, PB 58700-000, Brazil. *Corresponding author: franklin.riet@pq.cnpq.br

${ }^{3}$ Departamento de Clínica e Cirurgia, Centro de Ciências Agrárias, Universidade Federal do Piauí, Campus Universitário Petronio Portella s/n, Bairro Ininga, Teresina, PI 640495-550, Brazil.

${ }^{4}$ Biomedical Laboratory Diagnostics Program, Department of Microbiology and Molecular Genetics, Michigan State University, East Lansing, MI 48824, USA.
}

RESUMO.- [Surtos de zigomicose rinofacial e rinofaríngea em ovinos na Paraíba.] Dois surtos de lesões rinofaciais e dois de lesões rinofaríngeas causadas por fungos com hifas filamentosas, raramente septadas, semelhantes às dos fungos entomophthorales, são descritos no Estado da Paraíba. Um surto da forma rinofacial afetou 5 ovinos durante a estação chuvosa. Outro surto desta forma clínica afetou um ovino de um grupo de 40, durante a época seca. Os sinais clínicos da forma rinofacial foram de corrimento serosanguinolento bilateral, com aumento de volume das 
narinas, lábio superior, e pele da face. Na necropsia, a mucosa nasal apresentava áreas ulceradas de cor marrom escuro, que se estendiam desde a região muco-cutánea até $10 \mathrm{~cm}$ dentro do vestíbulo nasal. A mucosa do palato duro estava, também, ulcerada. A superfície de corte das narinas e palato apresentava-se marrom ou avermelhada de aspecto esponjoso e friável. Um surto de rinofaringite micótica ocorreu em uma plantação de coco irrigado, afetando 7 ovinos de um rebanho de 60 ovinos adultos. Outro surto desta forma da enfermidade afetou um único animal de um rebanho de 80 , durante a época seca. Os animais apresentavam dispnéia, com respiração ruidosa devida ao bloqueio parcial das narinas, e corrimento nasal serosanguinolento. Seis dos oito animais afetados por esta forma da enfermidade apresentaram, em um olho, exoftalmia, ceratite e ulceração da córnea. Todos os ovinos morreram ou foram sacrificados após um curso clínico de 7-30 dias. Na necropsia exsudato amarelo consistente foi observado na região etmoidal, ossos turbinados, seios paranasais, palatos duro e mole, órbita, faringe, e músculos e linfonodos regionais. No estudo histológico, ambas as formas da doença mostraram granulomas multifocais com áreas necróticas eosinofílicas (material de Splendore-Hoeppli) contendo hifas com 7-30um de diâmetro, raramente septadas, semelhantes às dos fungos entomophthorales, possivelmente Conidiobolus spp. Surtos de ambas as formas de rinite micótica são freqüentes na região semi-árida e em outras regiões do Brasil.

TERMOS DE INDEXAÇÃO: Conidiobolomicose, zygomicose, ovinos, semi-árido.

\section{INTRODUCTION}

Zygomycosis is a granulomatous fungal disease of humans and animals caused by several species of fungi with ribbontype coenocytic (aceptate) hyphae. Within the pathogenic zygomycetes two orders are of medical and veterinary importance: the Mucorales commonly involved in systemic zygomycosis (Mucor, Rhyzopus, Absidia, and other genera), and the Entomophthorales primarily causing subcutaneous zygomycosis (species of Conidiobolus and Basidiobolus). Subcutaneous zygomycosis caused by Conidiobolus coronatus, $C$. lamprauges and $C$. incongruus commonly involve the subcutaneous tissues of the face and nostrils in horses (Chauhan et al. 1973, Humber et al. 1989, Miller \& Campbell 1982, 1984, Bridges et al. 1962, Mendoza \& Alfaro 1985), dogs (Grooters 2003), sheep (Carrigan et al. 1992,Ketterer et al. 1992) and humans (Williams 1969, Valle et al. 2001). Basidiobolus ranarum (haptosporus) causes infection of the subcutaneous tissues located in anatomical areas other than the face in horses (Connole 1973, Miller \& Pott 1980, Miller \& Campbell 1982, 1984, Owens et al. 1985), and dogs (Miller \& Turnwald 1984, Greene et al. 2002, Grooters 2003), including a gastrointestinal form in humans (Burkitt et al. 1964, Williams 1969, Aguiar et al. 1980, Lyon et al. 2001). In addition, Pythium insidiosum, a fungal-like organism in the kingdom Stramenopila, has been reported causing eosinophilic granulomas with the Splendore-Heoppli phenomenon and slender sparsely septate hyphae in humans and animals including sheep (Tabosa et al. 2004).

Outbreaks of sheep mycotic rhinitis with histological characteristics of subcutaneous zygomycosis are frequently diagnosed in the semiarid region of northeastern Brazil. The disease occurs in two different clinical forms: a rhinofacial infection affecting the nose vestibule, mucoepithelial junction, and upper lip (Barbosa 2003, Riet-Correa et al. 2003, Silva 2003), and a nasopharyngeal infection affecting the ethmoidal region, turbinate bones, paranasal sinuses, hard and soft palates and pharynges (Silva et al. 2007a,b). This study reports four outbreaks of mycotic rhinitis, two affecting the rhinofacial region and other two affecting the rhinopharyngeal region, in sheep in state of Paraíba, northeastern Brazil.

\section{MATERIALS AND METHODS}

Epidemiological and clinical data were collected at the four studied farms located in the state of Paraíba, northeastern Brazil. Four animals were transported to the Veterinary Hospital of the University of Campina Grande, Paraíba, where they were examined in more detail. Necropsies were performed on sheep that died of their infections and on those that were euthanized in extremis. Samples from the nostril areas, peripheral lymph nodes, tissues from organs of the abdominal and thoracic cavities and central nervous tissues were fixed in $10 \%$ buffered formalin and examined histologically after being embedded in paraffin, sectioned at $6 \mu \mathrm{m}$, and stained with hematoxylin-eosin (HE). Selected sections were also stained by Periodic Acid Schiff (PAS) and Gomori's methenamine silver stains for fungi. In addition, a biopsy was taken from a sheep belonging to the first outbreak with lesions mostly on the nasal vestibule for histolopathological studies. The identification of the filamentous fungi involved in these cases was based on the morphological features observed in the histopathological preparations and also on the results obtained on all tissue sections stained with a serological assay using antiPithium insidiosum fluorescent antibodies (Perez et al. 2005), to rule out this stramenopilan pathogen.

\section{Rhinofacial zygomycosis \\ Epidemiology and clinical signs. One outbreak}

\section{RESULTS} occurred in the municipality of São José das Espinharas, Paraíba, in a flock of 40 Santa Inês bred hair sheep. These animals were kept in natural pastures during the day and were confined to enclosed barns during night time. All studied sheep were supplemented with corn bran. In this flock, four sheep were affected with the rhinofacial form during the rainy season, between February and May 2001. Two sheep (Sheep 1 and 2) were sent to the Veterinary Hospital at the University of Campina Grande. Sheep 1 was an 18-month-old ewe, admitted in May 2001, which had bilateral serosanguineous nasal discharge. The nostrils were swollen affecting the mucosa and mucocutaneous junction. The upper lip and the skin of the face, up to $10 \mathrm{~cm}$ from the nostrils, were also swollen. The animal had respiratory difficulties and noisy respiration due to stenosis of the nostrils. The left was more affected than 
the right nostril. This sheep died 14 days after admission. Sheep 2 was 18 months old. On admission at the Veterinary Hospital it had a nasal discharge and swollen nostrils with an ulcerated lesion on the mucocutaneous region of the right nostril. The nasal discharge had been observed by the farmer 8 days before admission. A biopsy was taken from this lesion. This sheep was treated orally with $7 \mathrm{mg} / \mathrm{kg}$ of potassium iodide, daily. On the 5 th day of treatment the lesion was considerably reduced, however, the animal died.

The second outbreak affected a 42 months old ram (Sheep 3), from a flock of 40 sheep of different ages in the Municipality of São José de Espinharas during the dry season. The flock was in an area around a large pond for long periods of time. Clinical signs were nasal hemorrhagic discharge and swelling of the left nostril. The animal was treated without results with potassium iodide orally during 2 months and locally with a spray containing $2 \%$ ketoconazol for 3 more months. The animal was euthanized after a clinical course of 6 months.

Pathology. At necropsy of Sheep 1, the nasal mucosa had a dark brown ulcerated area, extending from the mucocutaneous region to $10 \mathrm{~cm}$ inside the nasal vestibule (Fig.1). The mucosa of the hard palate had also a large ulcerated area, extending from the dental pad to the first premolars. The cut surface of the nostrils and palate had

Fig.1. Sheep 1. Longitudinal section of the nose. There is a necrotic brownish or red spongeous tissue in the subcutaneous tissue, nasal vestibule and hard palate.

Fig.2. Sheep 3. Nasal vestibule. A hyphal structure (arrow) is surrounded by Splendore-Hoeppli material. Few neutrophils, undifferentiated mononuclear cells, macrophages and collagenous fibers are present around the Splendore-Hoeppli material. HE, obj.20x.

Fig.3. Sheep 1. Nasal vestibule. Thin-walled, ribbon-type rarely septated hyphae are observed in the center of the lesion. Gomori's methenamine silver stain, obj.40x.

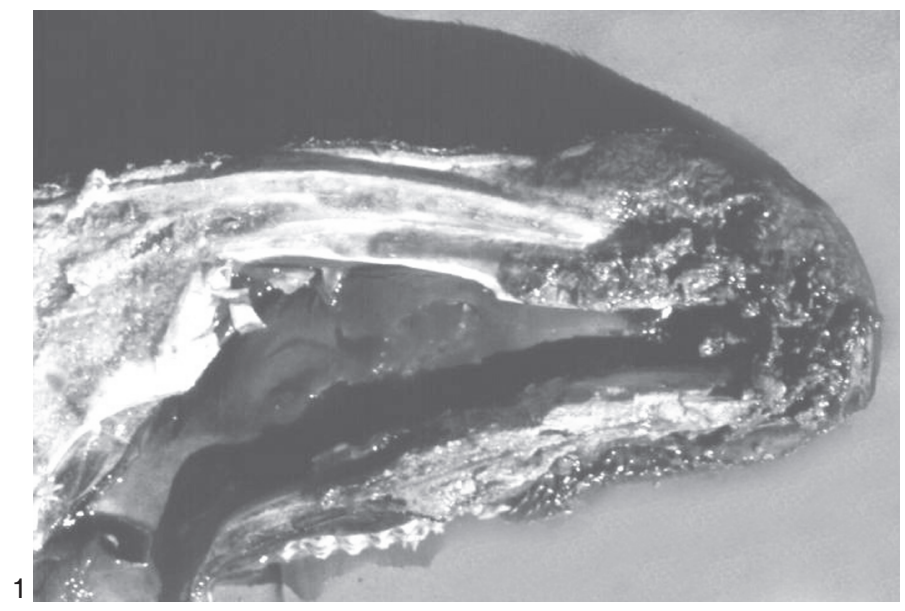

a brown or reddish spongeous tissue with a friable consistency. Red areas and cavitations surrounded by tissue with a necrotic appearance were observed within this tissue. Sheep 2 had a small $2-3 \mathrm{~cm}$ nodular lesion on the internal side of the mucocutaneous junction at the right nostril. In Sheep 3 the left nostril was dilated and a dark reddish area of necrosis was observed in the nasal vestibule, extending from the mucucutaneous junction to the ventral turbinate bone.

On histological examination, the lesions of the 3 sheep were characterized by multifocal eosinophilic abscesses with central areas of necrosis with eosinophils and eosinophilic granular material, containing hyaline ribbontype hyphal structures. Splendore-Hoeppli material was observed around the hyphal structures (Fig.2). Eosinophils, lymphocytes, undifferentiated mononuclear cells, plasma cells, and with less frequency neutrophils and macrophages were observed surrounding the necrotic centers (Fig.2). Thin collagenous fibers were observed within these exudates. Congestion, edema and hemorrhages were present in some areas. With Gomori's methenamine silver stain the hyphae appeared thin-walled, ribbon-type rarely septate hyphae (Fig.3), with little lateral branching and varying considerably in width, from 7-14 $\mu \mathrm{m}$. There was no evidence of vascular invasion or colonization by the fungi in these structures.
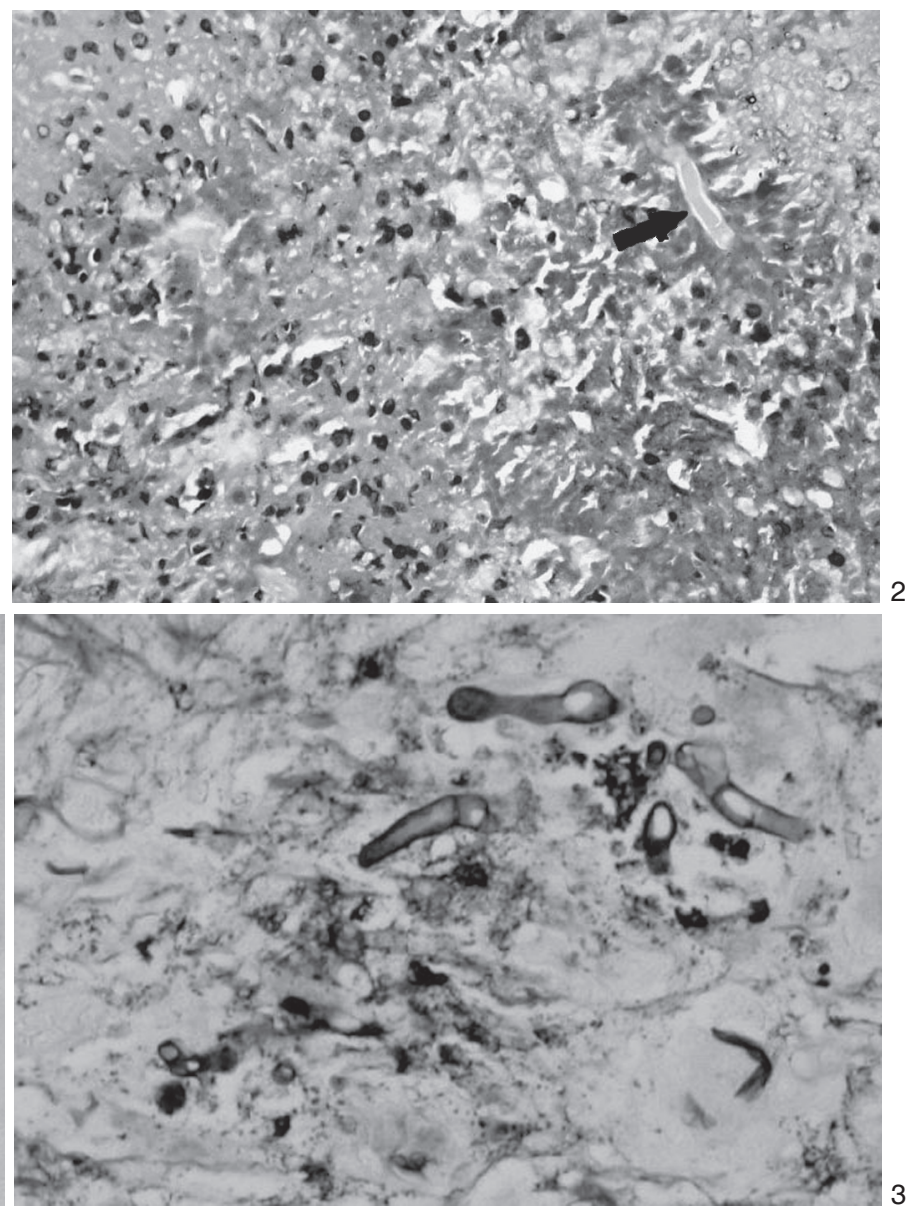


\section{Nasopharyngeal zygomycosis}

Epidemiology and clinical signs. One outbreak occurred in the municipality of Souza, Paraíba, during the raining season, from January to May 2004, affecting a flock of 120 hair sheep of the Santa Inês and Carirí breeds. The disease involved the nasopharyngeal area of 7 out of 60 adult sheep. The flock grazed in an irrigated area of coconut culture. Clinical signs were noisy respiration and dyspnoea due to mechanical blockage of the nasal cavities, swelling of the nostrils, and serosanguineous nasal discharge. In five of the seven affected sheep exophthalmia on one of the sheep's eye was observed, usually approximately 5 days after the initial signs of the infection. All affected animals died after a clinical course of seven to 15 days. Two of the seven sheep (Sheep 4 and 5) were sent to the Veterinary Hospital of the Federal University of Campina Grande, Paraíba for further analysis. Both sheep had clinical signs similar to those above mentioned, but exophthalmia was not observed in these animals. Sheep 4 was treated orally with $1 \mathrm{~g}$ potassium iodide daily for 7 days, but its clinical signs continue and a severe ocular discharge followed by a complete corneal opacity of the left eye was observed after 7 days of treatment. This sheep was euthanized 10 days after admission due to its bad clinical condition. Sheep 5 was also in bad clinical condition and thus, euthanized soon after arrival.

Another outbreak affects an 18 months old ram (Sheep 6) from a flock of 80 sheep in the municipality of Mãe D'água, Paraíba. During the day the flock was grazing in an area in the border of a large pond and, at night it was kept indoor supplemented with concentrate food. The main clinical signs were swelling of the right frontal region and exophthalmia of the right eye. After some days of exophthalmia the animal showed increased volume of the eyeball, blindness, keratitis and corneal hemorrhages and ulceration (Fig.4). It was treated with penicillin and streptomycin without results; the sheep lost weight rapidly and was euthanized one month after the first clinical signs appeared.

Pathology. At necropsy, Sheep 4 showed in the longitudinal medial section of the head two separate lesions. One was extended from the basisphenoid and presphenoid bones to the pharynges, which full of necrotic yellowish material. The lesion was $7 \mathrm{~cm}$ craniocaudally by $4 \mathrm{~cm}$ dorsoventrally. The soft palate, the auditive tuba, the pterigoid muscles and the retropharyngeal lymph nodes were also affected. The frontal and maxillary sinuses contained a similar exudate and a yellow firm mass in the left orbit, caudal to the eye and around the optic nerve. Another similar lesion was observed on the nasal ventral turbinate bone measuring $7 \mathrm{~cm}$ craniocaudally by $2 \mathrm{~cm}$ dorsoventrally, extending up to $1 \mathrm{~cm}$ from the nostrils. The ventral turbinate bone was partially destroyed and the meatus was full of yellow exudate. A circular lesion measuring approximately $2 \mathrm{~cm}$ in diameter with yellow firm exudates and surrounded by a reddish tissue was observed in the caudal left lobe of the lung. No macroscopic lesions were observed in anatomical areas other than the affected tissues.

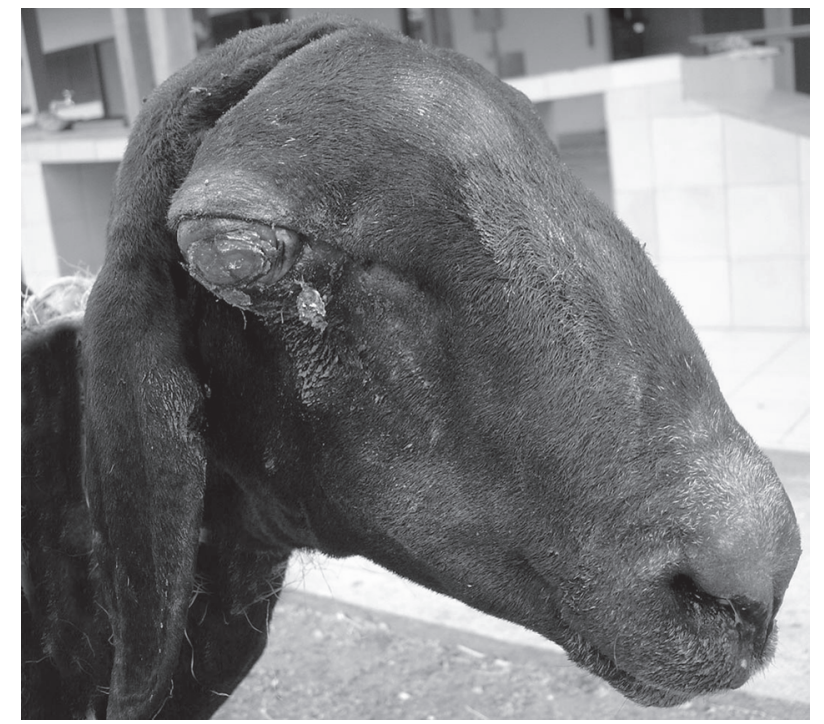

Fig.4. Sheep 6. The right eye has exophthalmia with increased volume of the eyeball, keratitis, and corneal haemorrhages and ulceration.

Sheep 5 showed on the medial longitudinal section of the head, a yellow, sometimes hemorrhagic exudate with hard consistency confined to the nasopharyngeal region. This area with exudate measured $8 \mathrm{~cm}$ craniocaudally, from the ethmoid to the middle of the dorsal and ventral turbinate bones, by $6 \mathrm{~cm}$ dorsoventrally, from the dorsal turbinate bone to the soft palate (Fig.5). The turbinates and ethmoid bones, soft and hard palates, the vestibule of the pharynges, and the periostal surface of the presphenoid bone and volmer were affected. The wall of the turbinate and ethmoturbinate bones was thickened or reabsorbed, and yellow exudate was observed in the meatus. The sphenoidal sinus was fully substituted by the yellow exudates. The soft palate was ulcerated and the lesion protruded into the oral cavity.

In Sheep 6, gross lesions of the nose were similar than those observed in the previous outbreak involving the nasopharingeal area. This sheep showed also numerous multifocal subpleural nodules in one of the lungs (Fig.6). The lesions were characterized by several well demarcated, slightly raised, yellow or reddish, non-ulcerated, nodules, $0.5-1 \mathrm{~cm}$ in diameter; the cut surface was whitish or yellowish bordered in red (Fig.6).

On histopathology of Sheep 4, 5 and 6, with hematoxilineosin stain, lesions were characterized by multifocal, sometimes coalescent, granulomas with a necrotic center with an eosinophilic granular aspect (Fig.7 and 8). Wide rarely septate hyphae were seen as clear spaces delineated by a narrow eosinophilic band within the lesion (Fig.7 and 8). A characteristic Splendore-Hoeppli material was present around most studied hyphae (Fig.8). A necrotic area containing necrotic eosinophils and neutrophils and, occasionally, granular eosinophilic deposits surrounded the hyphae (Fig.8). On the Gomori's methenamine silver stain the ribbon-type hyphae appeared thin walled, rarely septate, 


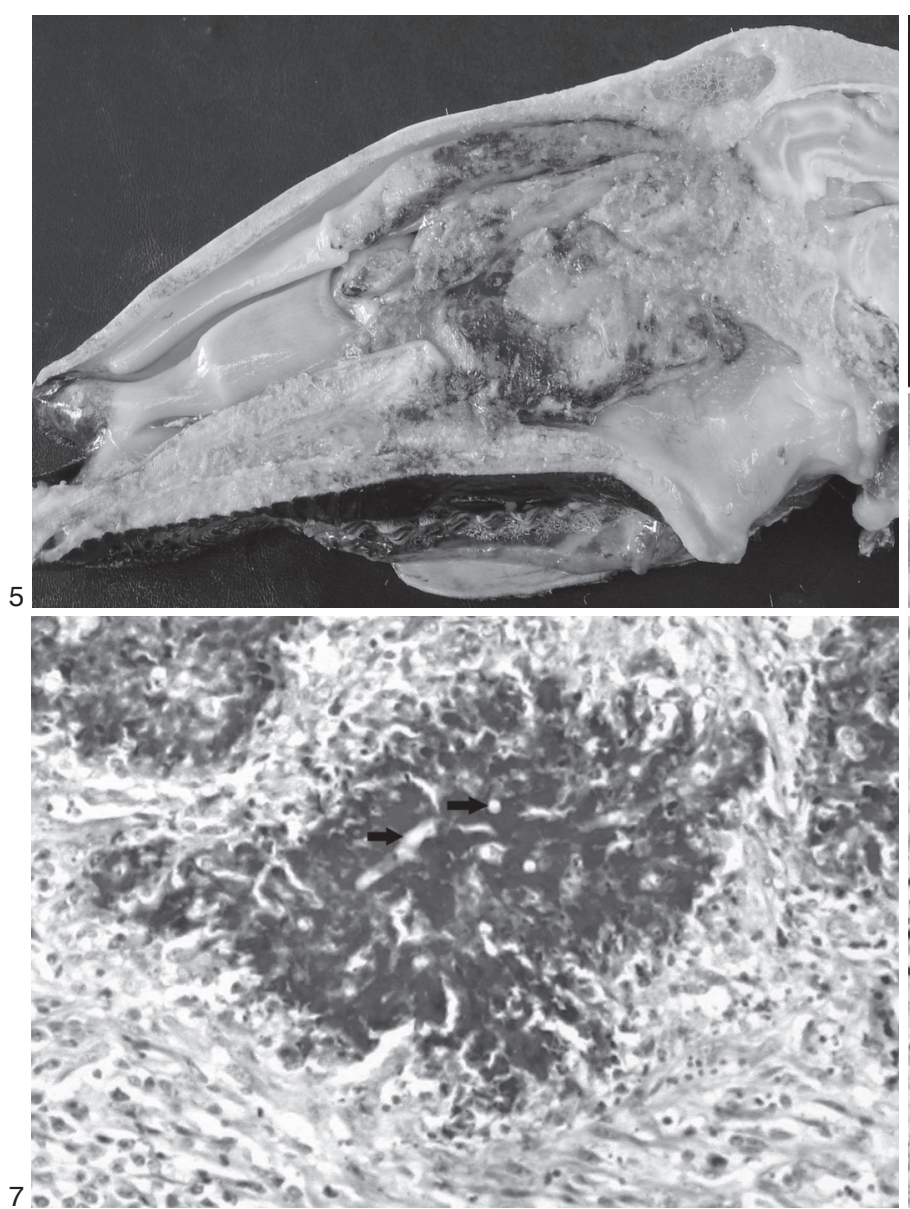

Fig.5. Sheep 5. Longitudinal section of the head showing a yellow, sometimes hemorrhagic exudate with hard consistency in the turbinate bones, etmoidal region and pharynges.

Fig.7. Sheep 7. Nasopharingeal region. Multifocal eosinophilic lesions containinig clear hyphae structures (arrows) surrounded by a characteristic Splendore-Hoeppli material and few neutrophils and eosinophils. Macrophages, undifferentiated mononuclear cells and connective tissue are present around the lesion. HE, obj.10x.

with lateral branching and varying considerably in width, 8$30 \mu \mathrm{m}$ (Fig.9). The outer part of the lesion contained connective tissue infiltrated mainly by lymphocytes, undifferentiated mononuclear cells and plasma cells (Fig.7 and 8). In more chronic lesions numerous giant cells, machrophages, some mononuclear undifferentiated cells and fibrous tissue were observed around the SplendoreHoeppli material. Congestion and hemorrhages were frequent. The nasal epithelium was hyperplastic, but rarely ulcerated. In the affected bone an increased number of osteoclasts and resorption surfaces were observed. The lesion also extended to the neighboring muscles and the retropharyngeal lymph nodes. There was no evidence of vascular invasion or colonization by the fungi. The lung lesions in two sheep were characterized by multifocal, sometimes confluent necrotic, eosinophilic areas containing

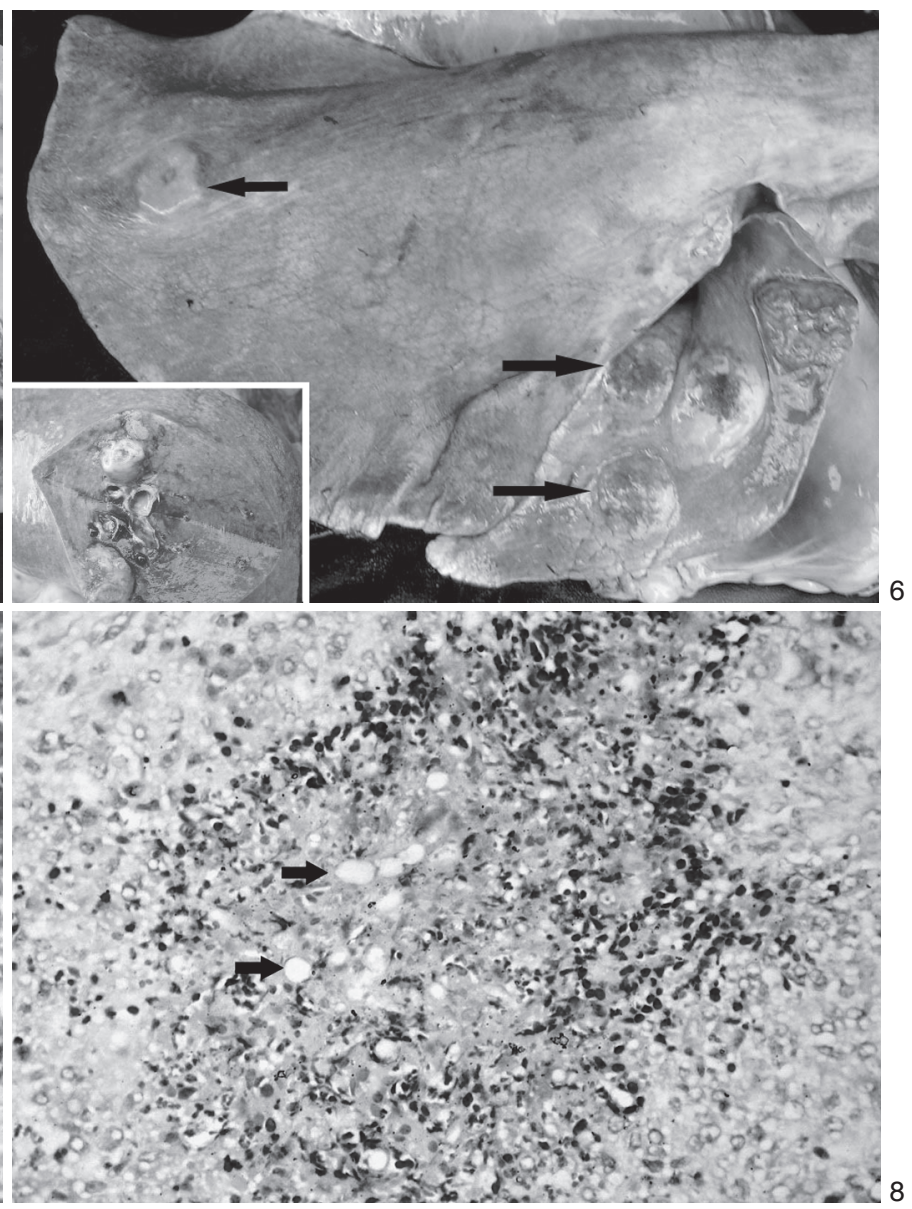

Fig.6. Sheep 6. Lung showing numerous multifocal subpleural nodules, $0.5-1 \mathrm{~cm}$ in diameter (arrows). Inset: Cut surface of the lung showing whitish or yellowish nodules bordered in red.

Fig.8. Sheep 4. A necrotic center containing clear hyphae structures (arrow), eosinophilic material and numerous necrotic eosinophils and neutrophils. Macrophages and undifferentiated mononuclear cells are surrounding the necrotic center. HE, obj.20x.

ribbon-type coenocytic hyphae. Between the eosinophilic material, unidentified mononuclear cells, macrophages, neutrophils and some eosinophils were observed. The periphery of the lesion was formed by a mixture of mononuclear cells, neutrophils, eosinophils, epitheliod and giant cells, fibroblasts and collagen.

\section{DISCUSSION}

In northeastern Brazil, cases of rhinofacial mycosis, sometimes known as "focinho de touro" (bull nose) (Barbosa 2003, Riet-Correa et al. 2003, Silva 2003), and micotic rhinopharyngitis (Silva et al. 2007a,b) are commonly clinically diagnosed. Rhinofacial mycosis has been observed also in sheep from other Brazilian regions (Castro 2007). Although in our study we did not included samples for culture, Conidiobolus coronatus from cases 


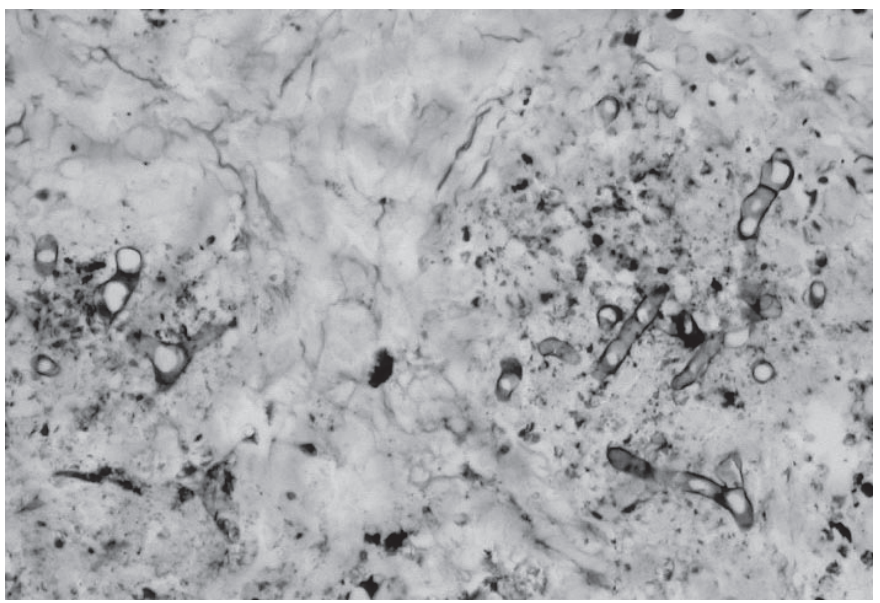

Fig.9. Sheep 4. Thin-walled, ribbon-type rarely septate hyphae are observed in the center of the Iesion. Gomori's methenamine silver stain, obj.40x.

of rhinopharyngitis (Silva et al. 2007a,b) and C. lampragues from a case of rhinofacial infection in the state of Piauí, Brazil have been recently isolated (Mendoza 2006). In addition, Pythium insidosum was also isolated from another case of rhinofacial infection in the same region where Conidiobolus infections have been long suspected (Mendoza 2007). These data indicate that the etiology behind rhinofacial and nasopharyngeal lesions with the presence of ribbon-type coenocytic hyphae more likely involve several etiologic agents.

In this study the histopathological description of the lesions were typical of that in the entomophthoramycetous fungi, with the presence of Splendori-Hoeppli material around $7-30 \mu \mathrm{m}$ in diameter thick, rarely septate, thin walled ribbon-type fungal elements, with occasional lateral branching hyphae. The histologic appearance and the location of the lesions in the rhinofacial and rhinopharyngeal area strongly support the hypothesis that the sheep disease in the State of Paraíba is caused by Conidiobolus species. Another agent that causes similar histopathological findings is $P$. insidiosum, but in pythiosis the Splendori-Hoeppli reaction is more discrete and the hyphae have thick walls and they are slender. Although recently $P$. insidiosum was reported in Brazilian sheep (Tabosa et al. 2004), paraffin included samples of the lesions examined for $P$. insidiosum by immunohistochemical methods in this study were consistently negative.

The finding of only rhinofacial lesions in the studied cases from one outbreak and rhinopharyngeal lesions in the other outbreak suggests that there are two different forms of the disease possibly involving multiple Conidiobolus species and P. insidiosum (Mendoza 2006, 2007, Silva et al. 2007a,b). The rhinofacial form involved the nasal vestibule, facial skin, and hard palate, and the other form affects the nasopharyngeal region, including the ethmoidal region, turbinate bones, paranasal sinuses, hard and soft palates, orbital cavity, pharynges, and regional muscles and lymph nodes. In the latter, the extension of the lesion to the orbit causes exophthalmia and other lesions of the eye. We believe that the occurrence of two different clinical forms of the disease can be attributed to the causal agent, or to different epidemiological conditions. Rhinofacial and rhinopharyngeal zygomycosis caused by Conidiobolus incongruus, similar to the disease observed in Paraíba, have been reported in Australian sheep (Ketterer et al. 1992). In this report, both forms of the disease were observed on the same farm; one sheep had rhinofacial lesions, and four had rhinopharyngeal lesions, extending through the ethmoid bone to the frontal lobe of the brain (Ketterer et al. 1992). However, brain lesions were not observed in the cases from Paraíba, Brazil. The occurrence of a lung metastasis in two of the cases was probably due to the invasion of the lung through the respiratory airways. Metastatic lesions in lungs, brain, and occasionally in other tissues were also observed in sheep with rhinopharyngitis caused by Conidiobolus coronatus in the state of Piauí, Brazil (Silva et al. 2007a).

In the rhinopharyngeal form, an interesting feature of the disease was the rapid clinical progression of the lesions (7-15 days in most animals). However, the chronicity observed in histopathological preparations suggests that it took considerable time to develop this type of pathology in the infected tissues. Because pain is rarely reported in infections caused by the entomophthoraceous fungi, it is probable that the lesions in sheep are also painless, thus the affected animals do not show clinical signs until the occurrence of respiratory distress or exophthalmia with blindness. The period of time between the beginning of the disease and the first clinical signs of the infection is probably the reason why treatment with potassium iodide is usually unsuccessful. In humans and other animals, potassium iodide has been the traditional and effective treatment against Conidiobolus infections (Owens et al. 1985). Several other drugs, such as: amphotericin B, cotrimoxazole, ketoconazole, itraconazole and fluconazole have been also effective in humans and animals with the disease (Moraes et al. 1994, Valle et al. 2001, Grooters 2003). Interestingly, in one case of rhinofacial form of the disease, the treatment with iodides of one affected animal with early clinical signs of the disease was partially successfully, suggesting that in the early form of the disease the treatment could be successful if it is initiated immediately after the observation of the first clinical signs.

There is not much data on the epidemiology of the disease in the tropical northeastern Brazil, except that the occurrence of this disease coincides with the rainy season (Silva et al. 2007a,b). Probably the sheep become infected by inhalation of the entomophthoraceous fungal conidia while they are feeding and the nostrils are close to the ground. In the rhinopharyngitis form conditions associated with the irrigation of the coconuts, including the presence of considerable amounts of decaying vegetation in a wet environment, are probably risk factors for the occurrence 
of Conidiobolus spp. and other entomophthoraceous fungi on that particular soil. Entomophthoraceous fungi are saprophytes that are distributed widely in natural environments throughout the world, including soil and decaying plant matter (Chandler et al. 1984). In the Australian outbreak the disease was associated with sheep in swampy areas (Ketterer et al. 1992) Conidiobolus coronatus, $C$. lamprauges, $C$. incongruus and other species have been commonly associated with this anatomical area (Chandler et al. 1984). Isolation of these species in pure culture from nostril, and facial areas, confirmed the predilection of Conidiobolus spp. for this type of tissues (Bridges et al 1962, Miller \& Campbell 1982, 1984, Mendoza \& Alfaro 1985, Humber et al. 1989, Carrigan et al. 1992, Valle et al 2001). Although Basidiobolus ranarum can also cause eosinophilic subcutaneous infections in apparently healthy individuals, this zygomycetous fungus is more common on limbs and anatomical areas other than the face (Miller \& Pott 1980, Owens et al. 1985, Greene et al. 2002, Grooters 2003). Zygomycetes in the Mucorales can also affect the face, but generally, these etiologic agents are opportunistic and do not trigger an eosinophilic response in the infected hosts (Willians 1969, Symmers 1972). These and other criteria were used in our study to histopathologically classify the fungal hyphal structures observed in the infected tissues as hyphal elements of the enthomophthoraceous zygomycetes, possibly Conidiobolus species.

\section{REFERENCES}

Aguiar E., Moraes W.C. \& Londero A.T. 1980. Gastrointestinal entomophthoramycosis caused by Basidiobolus haptosporus. Mycopathologia 72:101-105.

Barbosa J.D. 2003. Unpublished data (Federal University of Pará, Castanhal).

Bridges C.H., Romane W.M. \& Emmons C.W. 1962. Phycomycosis of horses caused by Entomophthora coronata. J. Am. Vet. Med. Assoc. 140:673-677.

Burkitt D.P., Wilson A.M.M. \& Jelliffe D.B. 1964. Subcutaneous phycomicosis: a review of 31 cases seen in Uganda. Brit. Med. J. 1:1669-1672.

Carrigan M.J., Small A.C. \& Perry G.H. 1992. Ovine nasal zygomycosis caused by Conidiobolus incongruus. Aust. Vet. J. 69:237-240.

Castro M. 2007. Unpublished data (University of Brasília, DF).

Chandler F.W., Kaplan W. \& Ajello L. 1980. A Color Atlas and Text Book of the Histopathology of Mycotic Diseases. Year Book Medical Publisher, Chicago, p.104-105.

Chauhan H.V.S., Sharma G.L., Kalra D.S., Malhotra F.C. \& Kapur M.P. 1973. A fatal cutaneous granuloma due to Entomophthora coronata in a mare. Vet. Rec. 92:425-427.

Connole M.D. 1973. Equine phycomycosis. Aust. Vet. J. 49:215-216.

Greene C.E., Brockus C.W., Currin M.P. \& Jones C.J. 2002. Infection by Basidiobolus ranarum in two dogs. J. Am. Vet. Med. Assoc. 221:528532.
Grooters A.M. 2003. Pythiosis, lagenidiosis, and zygomicosis in small animals. Vet. Clin. Small Anim. 33:695-720.

Humber R.A., Brown C.C. \& Kornegay R.W. 1989. Equine zygomycosis caused by Conidiobolus lamprauges. J. Clin. Microbiol. 27(3):573-576.

Ketterer P.J., Kelly M.A. \& Connole M.D. 1992. Rhinocerebral and nasal zygomycosis in sheep caused by Conidiobolus incongruus. Aust. Vet. J. 69:85-87.

Lyon G.M., Smilack J.D., Komatsu K.K., Pasha T.M., Leighton J.A., Guarner J., Colby T.V., Lindsley M.D., Phelan M., Warnock D.W. \& Hajjeh R.A. 2001. Gastrointestinal basidiobolomycosis in Arizona: clinical and epidemiological characteristics and review of the literature. Clin. Infect. Dis. 32:1448-1455.

Mendoza L. 2006. Unpublished data (Michigan State University, East Lansing, MI).

Mendoza L. 2007. Unpublished data (Michigan State University, East Lansing, MI).

Mendoza L. \& Alfaro A.A. 1985. Equine subcutaneous zygomycosis in Costa Rica. Mycosen 28:545-549.

Miller R.I. \& Pott B. 1980. Phycomycosis of the horse caused by Basidiobolus haptosporus. Aust. Vet. J. 56:224-227.

Miller R. \& Campbell R.S.F. 1982. Clinical observations on equine phycomycosis. Aust. Vet. J. 58:221-225.

Miller R. \& Campbell R.S.F. 1984. The comparative pathology of equine cutaneous phycomycosis. Vet. Pathol. 21:325-332.

Miller R.I. \& Turnwald G. 1984. Disseminated basidiobolusmycosis in a dog. Vet. Pathol. 21:117-119.

Moraes M.AP., Almeida M.M.R., Veiga R.C.C. \& Silveira F.T. 1994. Zigomicose nasofacial: relato de um caso no estado do Pará, Brasil. Ver. Inst. Med. Trop. 36:171-174.

Perez R.C., Luis-Leon J.J., Vivas J.L. \& Mendoza L. 2005. Epizootic cutaneous pythiosis in beef calves. Vet. Microbiol. 109:121-128.

Owens W.R., Miller R.I., Haynes P.F. \& Snider T.G. 1985. Phycomycosis caused by Basidiobolus haptosporus in two horses. J. Am. Vet. Med. Assoc. 186:703-705.

Riet-Correa F., Tabosa I.M., Azevedo E.O., Medeiros R.M., Simões S.V.D., Dantas A.F., Alves C.J., Nobre V.M.T., Athayde A.C., Gomes A.A. \& Lima E.F. 2003. Doenças dos ruminantes e eqüinos no semiárido da Paraíba. Semi-Árido em Foco, Patos, 1:2-86.

Silva S. 203. Unpublished data (Federal University of Piauí, Teresina). Silva S.M.M.S., Castro R.S., Costa F.A.L., Vasconcelos A.C., Batista M.C.S., Riet-Correa F., Carvalho E.M.S. 2007a. Conidiobolomycosis in sheep in Brazil. Vet. Pathol. 44:314-319.

Silva S.M.M.S., Castro R.S., Costa F.A.L., Vasconcelos A.C., Batista M.C.S., Riet-Correa F. \& Carvalho E.M.S. 2007b. Conidiobolomicose em ovinos no Brasil: Epidemiologia e sinais clínicos em 25 rebanhos. Pesq. Vet. Bras. 27:184-190.

Symmers W.C. 1972. Histopathology of phycomycosis. Ann. Soc. Belge. Med. Trop. 52:365-390.

Tabosa I.M., Riet-Correa F., Nobre V.M.T., Azevedo E.O., Reis-Junior J.L. \& Medeiros R.M. 2004. Outbreaks of pythiosis in two flocks of sheep in northeastern Brazil. Vet. Pathol. 41:412-415.

Valle A.C.F., Wanke B., Lazéra M.S., Monteiro P.C.F. \& Viegas M.L. 2001. Entomophthoramycosis by Conidiobolus coronatus: Report of a case successfully treated with the combination of itraconazole and fluconazole. Revta Inst. Med. Trop., São Paulo, 43:233-236.

Williams A.O. 1969. Pathology of phycomycosis due to Entomhophtora and Basidiobolus species. Arch. Pathol. 87:13-20. 